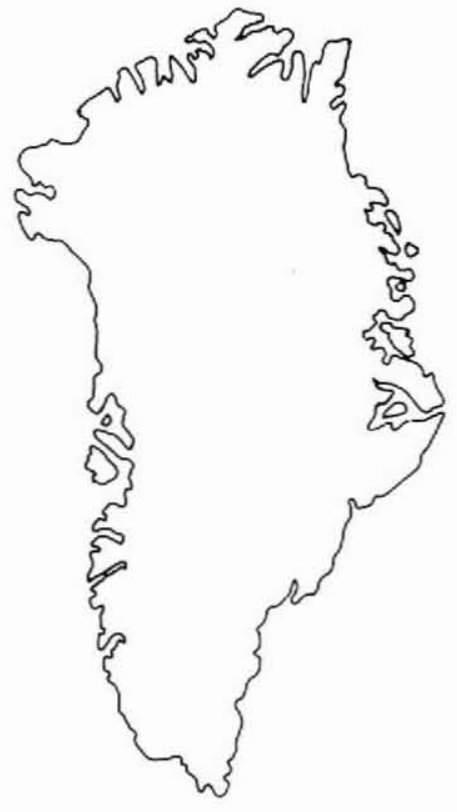

\title{
Effects of glaciers on annual runoff east of Nuuk/Godthåb, West Greenland
}

\author{
Roger J. Braithwaite
}

\begin{abstract}
The Kangerluarsunnguaq basin east of Nuuk/Godthåb has only a slight glacier cover while glaciers contribute about 80 per cent of the total runoff from Isortuarsuup Tasia. The two basins have similar seasonal variations of runoff and very different year-to-year variations. For example, annual runoff from Kangerluarsunnguaq closely follows annual precipitation variations in Nuuk, confirming that the basin is essentially a precipitation basin. By contrast, annual runoff from Isortuarsuup Tasia is in anti-phase to precipitation with a lower amplitude. This is an example of the 'glacier smoothing' effect whereby ablation variations tend to offset precipitation variations. However, runoff from Isortuarsuup Tasia is also influenced by icedammed lakes which absorb water for several years and then drain suddenly.
\end{abstract}

\section{R. J. B., Geological Survey of Greenland, Øster Voldgade 10, DK-1350 Copenhagen} $K$, Denmark.

Investigations have been made since the early $1980 \mathrm{~s}$ on the feasibility of supplying Nuuk/Godthåb with hydro-electric power. The basins concerned are the Kangerluarsunnguaq (KNNQ) and Isortuarsuup Tasia (ISTA) basins east and south-east of Nuuk (fig. 1). The effect of glaciers on runoff in these basins is discussed by Braithwaite (1989) with emphasis on planning hydropower while the present paper discusses scientific aspects, especially in comparison with runoff from Johan

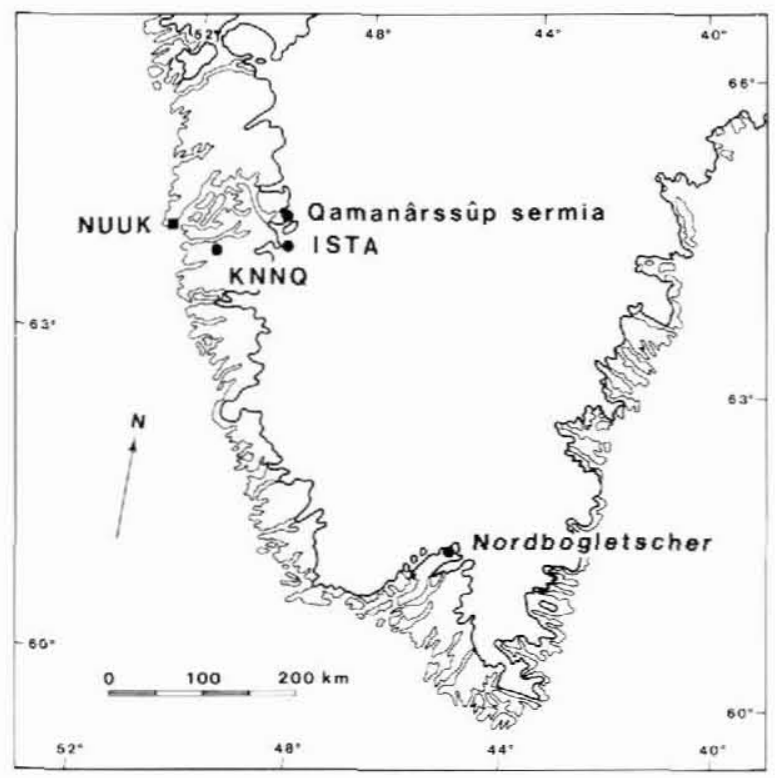

Fig. 1. Locations of the Kangerluarsunnguaq (KNNQ) and Isortuarsuup Tasia (ISTA) basins east and south-east of Nuuk.
Dahl Land, South Greenland (Braithwaite \& Olesen, 1988), and from near Ilulissat/Jakobshavn, West Greenland (Braithwaite \& Thomsen, 1989a).

\section{The setting}

The main hydrological and glaciological features of the Kangerluarsunnguaq and Isortuarsuup Tasia basins are shown in fig. 2 where the Roman numerals refer to sub-basins identified by the hydropower planners.

\section{Kangerluarsunnguaq}

The highest priority for hydropower is given to subbasin I draining to the lake $S \emptyset 249$. The basin has an area of $582 \mathrm{~km}^{2}$. Runoff measurements have been made at station 422 since 1981 by the Greenland Technical Organization (GTO, 1985, 1986). Although glaciers only occupy 1.8 per cent of the basin area (Weidick \& Thomsen, 1983, p. 56), accumulation and ablation measurements have been made on glacier 1CG14033 since 1982 (Braithwaite \& Thomsen, 1989b) to investigate the possible effect of glaciers on runoff.

\section{Isortuarsuup Tasia}

Although runoff has been measured at station 305 since 1976 the sub-basin IX draining to Sø 464 now has low priority for hydropower. The drainage area includes $441 \mathrm{~km}^{2}$ of ice-free land, about $95 \mathrm{~km}^{2}$ of local glaciers including a sector of a local ice cap (1CE05009), and a 

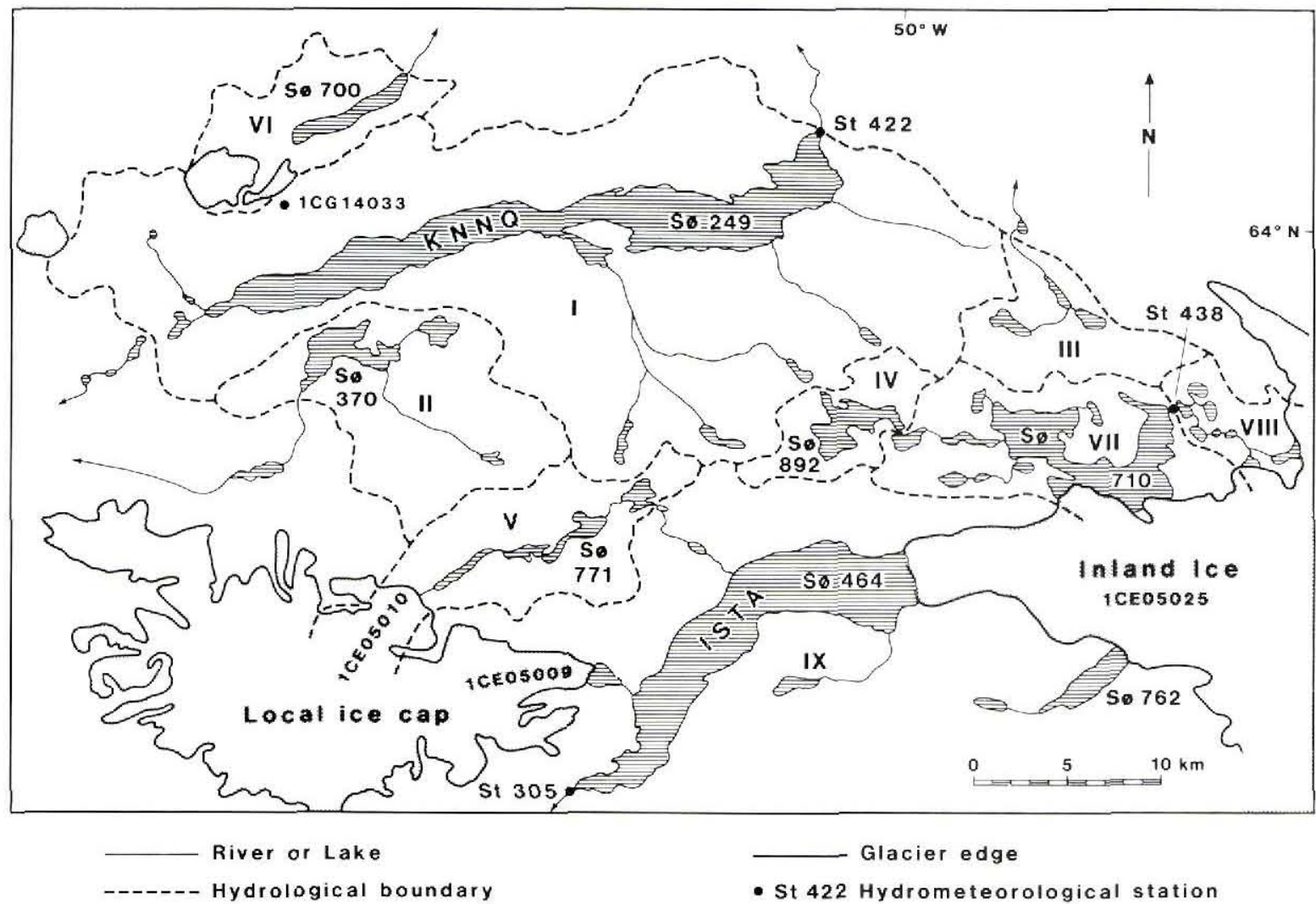

Glacier edge

- St 422 Hydrometeorological station

Fig. 2. Map of Kangerluarsunnguaq (KNNQ) and Isortuarsuup Tasia (ISTA). S $ø=$ lake, number indicates altitude.

sector of the Greenland ice sheet (1CE05025) with an estimated area of about $260-310 \mathrm{~km}^{2}$ according to Thomsen (personal communication). The basin therefore has about $45-48$ per cent glacier cover. The presence of some large ice-dammed lakes, especially $\$ \varnothing 710$ and $S \varnothing 762$, introduces a complication.

The contribution to runoff from glaciers can be estimated for the Isortuarsuup Tasia basin by assuming that the ice-free part of the basin $\left(441 \mathrm{~km}^{2}\right)$ has the same runoff per unit area as the Kangerluarsunnguaq basin $\left(582 \mathrm{~km}^{2}\right)$. The runoff from the ice-free part of Isortuarsuup Tasia is then (441/582) times the runoff from Kangerluarsunnguaq, and the runoff from the glacier part of the basin is the total runoff minus the estimated glacier-free runoff. The results of this estimation are given for 1981-1986 in Table 1 where data from Isortuarsuup Tasia for 1984 are missing. The results of this calculation suggest that glaciers contribute about 80 per cent of the total runoff from Isortuarsuup Tasia.

\section{Runoff variations}

The most important hydrological information for planning hydropower relates to the amount of water which is available, i.e. the runoff, and its seasonal and year-to-year variability. The runoff in any basin is a balance between rain, evaporation, meltwater from snow and ice, and storage changes in lakes. Kanger-

\section{Table 1. Annual runoff from} Kangerluarsunnguaq (KNNQ) and from glacierfree and glacier-covered parts of Isortuarsuup Tasia (ISTA)

\begin{tabular}{|c|c|c|c|c|}
\hline \multirow{2}{*}{$\begin{array}{l}\text { Year } \\
1981\end{array}$} & \multirow{2}{*}{$\frac{\text { KNNQ }}{281}$} & \multicolumn{3}{|c|}{$\begin{array}{c}\text { ISTA } \\
\text { Glacier-free }+ \text { Glacier }=\text { Total }\end{array}$} \\
\hline & & 212 & 637 & 849 \\
\hline 1982 & 150 & 113 & 533 & 646 \\
\hline 1983 & 329 & 248 & 508 & 756 \\
\hline 1984 & 282 & & & \\
\hline 1985 & 138 & 104 & 860 & 964 \\
\hline 1986 & 207 & 156 & 873 & 1029 \\
\hline Mean & 221 & 167 & 682 & 845 \\
\hline $\mathrm{c}, \mathrm{v}$ & $37 \%$ & $37 \%$ & $26 \%$ & $18 \%$ \\
\hline
\end{tabular}

Based on data from GTO (1985 \& 1986) Units are $10^{6} \mathrm{~m}^{3} \mathrm{a}^{-1}$ 


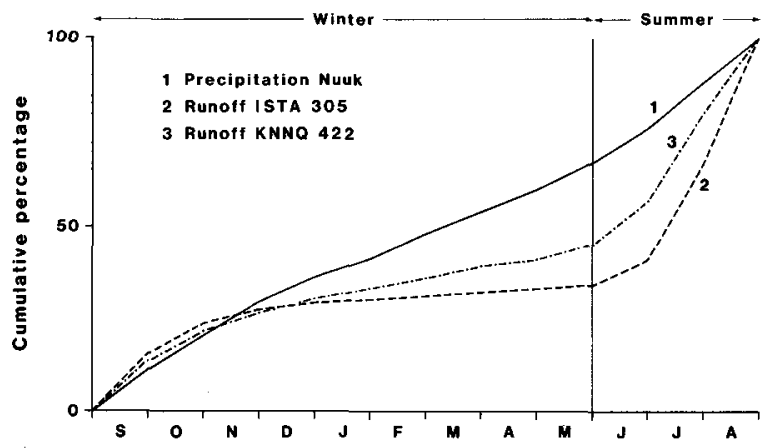

Fig. 3. Seasonal variations of precipitation in Nuuk and runoff from Kangerluarsunnguaq (KNNQ) and Isortuarsuup Tasia (ISTA).

luarsunnguaq has only a sparse glacier cover and can be regarded as a conventional precipitation basin while Isortuarsuup Tasia has an extensive glacier cover. Assuming the two basins are under essentially the same climate, differences in runoff variations between the two basins must be due to 'glacier effects', i.e. ablation and ice-dammed lakes.

\section{Seasonal variations}

Seasonal variations of runoff for the two basins are compared in fig. 3 with seasonal variations of precipitation in Nuuk. The data refer to cumulative averages throughout the year which are expressed as percentages of the respective annual totals. The precipitation curve is fairly straight but curves upwards in the periods September to November and June to August, indicating slightly heavier precipitation in the summer and autumn seasons compared with winter and spring. By contrast, the runoff curves for both basins only have gentle upwards slopes through the winter followed by steep rises in the summer, indicating a strong seasonal pattern of little runoff in winter and high runoff in summer. Comparison of the runoff and precipitation curves shows that most precipitation in the period November to May falls as snow and is stored until released by melting in June to August. Runoff and precipitation variations are fairly parallel in September and October because the snow cover has essentially disappeared while most precipitation falls as rain. There are differences between the two runoff curves which are partly due to glacier effects, especially stronger seasonal contrast for the glacier-fed Isortuarsuup Tasia basin, but these are fairly small compared with the larger differences between runoff and precipitation. This shows that the accumulation/melting cycle is the main control on seasonal variations of runoff.

\section{Year-to-year variations}

Annual runoff for the two basins are compared in fig. 4 with annual precipitation in Nuuk. The data refer to percentage deviations of annual runoff and precipitation from their respective longer-term averages (for 1981-1986). A hydrological year from September to August is used for the Nuuk precipitation total. The variations in KNNQ runoff and Nuuk precipitation are quite similar, confirming that Kangerluarsunnguaq is essentially a precipitation basin. This is in contrast with runoff from Isortuarsuup Tasia where runoff variation appears to be in anti-phase to precipitation variation and to have a lower amplitude. This is an example of the 'glacier smoothing' effect described by many authors, and found in South Greenland by Braithwaite \& Olesen (1988), whereby ablation variations tend to offset precipitation variations. However, in addition to precipitation and ablation, the runoff from Isortuarsuup Tasia is also influenced by the ice-dammed lake (Sø 710) to the north of glacier 1CE05025 (fig. 2), which drained in October 1980 and August 1986. There were therefore extra water volumes in these two years, corresponding to about $230 \times 10^{6} \mathrm{~m}^{3} \mathrm{a}^{-1}$ (GTO, 1983).

\section{Effect of ablation on runoff}

The effect of ablation on annual runoff is expressed by the correlation between runoff and ablation, and the correlation between runoff and precipitation (Braithwaite \& Olesen, 1988). A basin with little or no glacier cover has a positive correlation between runoff and precipitation and a negative correlation between runoff and ablation, while a basin with high glacier cover has a negative correlation between runoff and precipitation and a positive correlation between runoff and ablation. The amount of glacier cover also influences the runoff variability, e.g. the standard deviation of annual runoff

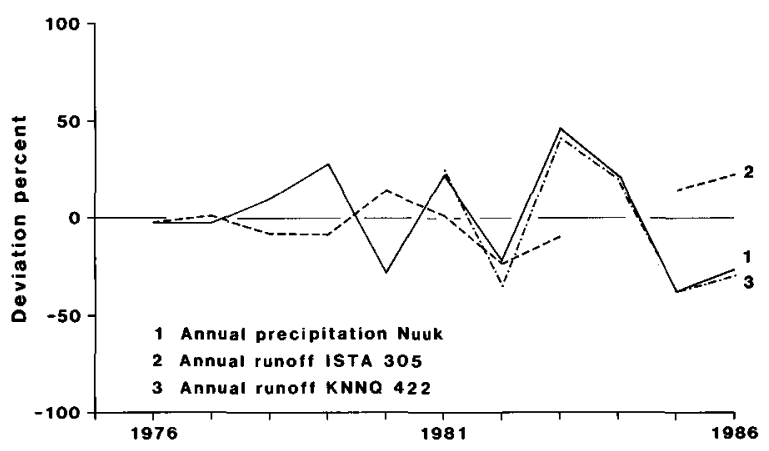

Fig. 4. Yèar-to-year variations of precipitation in Nuuk and runoff from Kangerluarsunnguaq (KNNQ) and Isortuarsuup Tasia (ISTA). 


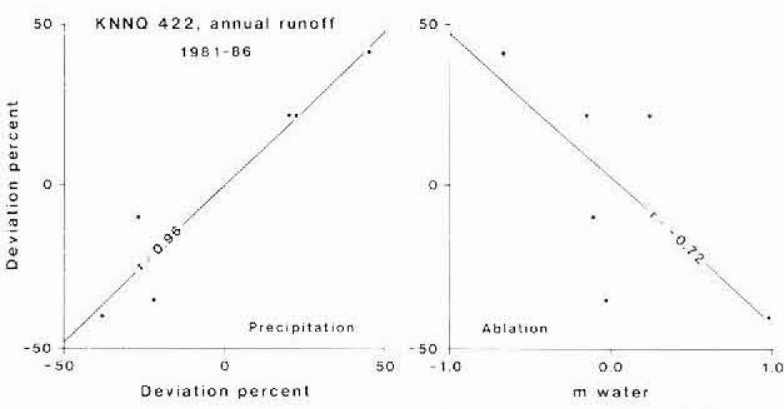

Fig. 5. Annual runoff from Kangerluarsunnguaq (KNNQ) versus annual precipitation (left) and annual ablation (right).

divided by the mean runoff, whereby a glacier-free ba$\sin$ has a relatively high runoff variability, decreasing to a minimum for basins with moderate glacier cover, and then increasing again for basins with high glacier cover.

The above pattern applies to runoff from glacier-free and moderately glacierized basins in Johan Dahl Land (Braithwaite \& Olesen, 1988) as well as to runoff from a highly glacierized basin north-east of Ilulissat (Braithwaite \& Thomsen, 1989a).

\section{Kangerluarsunnguaq}

Runoff variations are plotted against precipitation and ablation deviations respectively in fig. 5. Runoff and precipitation are expressed as percentage deviations from their respective means, and ablation is expressed as a simple deviation from mean ablation. The ablation data refer to measurements made on glacier 1CG14033 since 1983 which have been extrapolated back to 1981 by correlation with ablation deviations at Qamanârssûp sermia (Braithwaite \& Olesen, 1989a).

As expected, there is a high positive correlation between runoff and precipitation, and a fairly strong negative correlation between runoff and ablation. These features, together with the relatively high runoff variability (Table 1, fig. 4), are typical of a basin with sparse glacier cover.
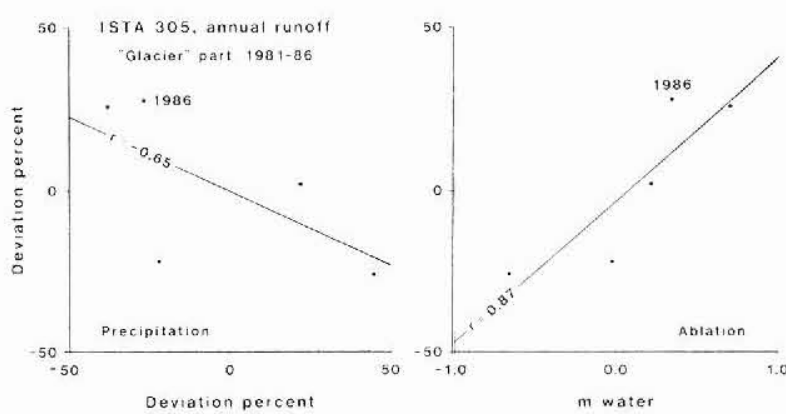

Fig. 6. Annual runoff from Isortuarsuup Tasia (ISTA) versus annual precipitation (left) and annual ablation (right).

\section{Isortuarsuup Tasia}

Runoff variations are plotted against precipitation and ablation deviations respectively in fig. 6 . The runoff data refer to the 'glacier part' in Table 1 and the ablation data are measured on Qamanârssûp sermia. In contrast to Kangerluarsunnguaq, there is a moderately negative correlation between runoff and precipitation, and a high positive correlation between runoff and ablation which is typical of a moderately to highly glacierized basin. However, in both plots, runoff for 1986 was higher than average due to the drainage of the ice-dammed lake in that year. Alternatively, the runoff in all the other years is lower than average because some water is stored in these years without contributing to runoff.

The total runoff from Isortuarsuup Tasia is a combination of the above glacier runoff, responding to ablation variations, with runoff from the glacier-free part of the basin, responding to precipitation variations. The variations in the two runoff components tend to offset each other such that the variability of total runoff is reduced, i.e. with a coefficient of variation (c.v.) of $18 \%$ compared with $37 \%$ and $26 \%$ respectively for icefree and glacier runoff components.

\section{Effect of storage on annual runoff}

The monthly runoff from Isortuarsuup Tasia (whole basin) is plotted against monthly mean temperature in Nuuk in fig. 7. As mean temperature is a good (slightly non-linear) index of ablation (Braithwaite \& Olesen, $1989 \mathrm{~b})$ the plot essentially represents a relation between runoff and ablation at a monthly level while deviations from a simple curve are caused by year-to-year and seasonal storage changes, superimposed upon rainfall variations.

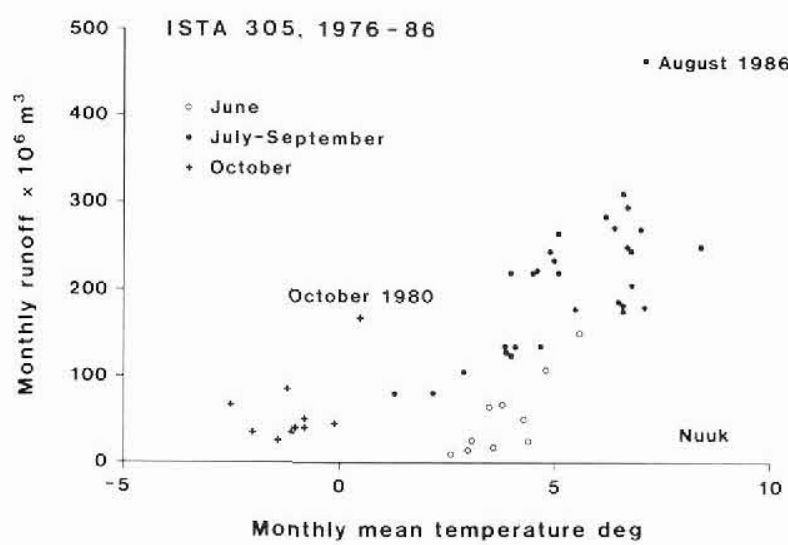

Fig. 7. Monthly runoff from Isortuarsuup Tasia (ISTA) versus monthly mean temperature in Nuuk. 
Runoff values for October 1980 and August 1986 were high compared with temperature due to the drainage of the ice-dammed lake ( $₫ \varnothing 710$ ), representing the effect of release from long-term storage. Aside from these two months, data for the other months appear to cluster around the expected non-linear runoff-temperature relation with October values clustered on the left and June values clustered on the right of the July to September values. The reason may be that runoff in the early part of the season (June) is reduced because some water goes into temporary storage in supraglacial and subglacial water bodies which are just beginning to form, while late season runoff (October) is augmented by the drainage of the same bodies. However, lake storage in the glacier-free parts of the basin will have a similar effect.

The Isortuarsuup Tasia basin presently has a low priority for planning hydropower. However, if this changes in the future, a detailed study on the filling/draining cycle of the ice-dammed lakes would be indicated.

\section{Outlook}

Exploitation of runoff from Kangerluarsunnguaq basin for hydropower will hardly involve any glaciological problems. However, glaciers strongly influence runoff from Isortuarsuup Tasia and some of the other subbasins that might be exploited in the future. For example, runoff in sub-basin $\mathrm{V}$ is almost certainly strongly influenced by ablation from a local ice cap (fig. 2) and should be investigated further.

Although glaciers have little effect on runoff from Kangerluarsunnguaq, there are indications that the summer runoff from the basin is correlated with snow accumulation measured in the spring on glacier 1CG14033 (Braithwaite \& Thomsen, 1989b), presumably because accumulation on the glacier is an index of the total snow storage in the basin. The possibility of using this correlation to make operational forecasts of summer runoff from Kangerluarsunnguaq is now under investigation.

\section{References}

Braithwaite, R. J. 1989: Glaciers and hydropower for Nuuk/ Godthåb, West Greenland. Open File Ser. Grønlands geol. Unders. 89/2, 49 pp.

Braithwaite, R. J. \& Olesen, O. B. 1988: Effect of glaciers on annual runoff, Johan Dahl Land, South Greenland. J. Glaciol. 34(117), 200-207.

Braithwaite, R. J. \& Olesen, O. B. 1989a: Detection of climate signal by inter-stake correlations of annual ablation data, Qamanârssûp sermia, West Greenland. J. Glaciol. 35(120), 253-259.

Braithwaite, R. J. \& Olesen, O. B. 1989b: Calculation of glacier ablation from air temperature, West Greenland. In Oerlemans, J. (edit.) Glacier fluctuations and climatic change, 219-233. Dordrecht: Kluwer Academic Publishers.

Braithwaite, R. J. \& Thomsen, H. H. 1989a: Simulation of run-off from the Greenland ice sheet for planning hydroelectric power, Jakobshavn/Ilulissat, West Greenland. Ann. Glaciol. 13, 12-15.

Braithwaite, R. J. \& Thomsen, H. H. 1989b: Improved accumulation measurements on glacier 1CG14033 near Nuuk/ Godthåb, West Greenland. Rapp. Grønlands geol. Unders. 145, 63-66.

GTO, 1983: Forundersøgelse vandkraft 1982, hydrologi, Buksefjorden, Nuuk/Godthåb. København: Rapp. Grønlands Tek. Org., $66 \mathrm{pp}$.

GTO, 1985: Generelle hydrologiske bassin-informationer GEHBI, bynære bassiner 1985. København: Rapp. Grønlands Tek. Org., 193 pp.

GTO, 1986: Generelle hydrologiske bassin-informationer GEHBI, bynære bassiner 1986. Supplement I. København: Rapp. Grønlands Tek. Org., 160 pp.

Weidick, A. \& Thomsen, H. H. 1983: Lokalgletschere og Indlandsisens rand i forbindelse med udnyttelse af vandkraft i bynære bassiner. Grønlands geol. Unders. Gletscher-hydrol. Meddr 83/2, 129 pp. 